\title{
A narrativa da experiência em foucault e Thompson
}

Fernando Nicolazzi*

Resumo. O texto tem por escopo analisar o conceito de experiência nos escritos de Michel Foucault e de Edward Thompson, especificamente a maneira como cada um dos autores organiza, no espaço de uma narrativa histórica, um campo de ação particular, caracterizado pela temporalidade da construção de um sujeito na história.

Palavras-chave: Michel Foucault. Edward Thompson. Experiência.

O tempo torna-se tempo humano na medida em que está articulado de modo narrativo; em compensação, a narrativa é significativa na medida em que esboça os traços da experiência temporal.

Paul Ricoeuer

Tempo e narrativa, termos que, se percebidos segundo uma reflexão teórica particular, bem poderiam ser intercambiados por uma expressão tão significativa quanto complexa: experiência histórica. Pois é seguindo tal reflexão, orientada pelos caminhos

\footnotetext{
* Professor substituto do Departamento de História da UFRGS, Doutorando em História na UFRGS e bolsista Capes.
}

Anos 90, Porto Alegre, v. 11, n. 19/20, p.101-138, jan./dez. 2004 
abertos por Paul Ricoeur, bastante explícitos na epígrafe que abre este texto, que traço algumas considerações sobre a maneira como Michel Foucault e Edward Palmer Thompson, cada qual através de sua respectiva postura intelectual, estabelecem os contornos disto que se poderia definir como uma experiência histórica, particularmente, o interesse reside na forma como ambos os autores, em textos propriamente historiográficos, organizam uma experiência de tempo em uma narrativa de história. De fundo, o que essas considerações permitem realizar é uma aproximação teórica entre as análises hermenêuticas de Ricoeur e os conceitos teóricos sobre os diferentes estratos de tempo desenvolvidos por Reinhardt Koselleck. ${ }^{1}$

\section{Michel Foucault e a experiência da sexualidade grega}

Tanto no prefácio de seu primeiro grande livro, História da loucura na idade clássica, publicado em 1961, quanto no último texto ao qual deu seu aval para publicação, antes de seu falecimento, em 1984, Michel Foucault utiliza o termo experiência de maneira não-despropositada. ${ }^{2}$ No primeiro caso, justificava-se tal emprego em virtude da consideração da loucura como uma experiência cujo estudo significaria "interrogar uma cultura sobre suas experiênciaslimite, [ou seja] questioná-la, nos confins da história, sobre um dilaceramento que é como o nascimento mesmo de sua história" (Foucault, 1999b, p.142). Experiência aqui, e salientando a perspectiva estrutural da análise de Foucault, significa um plano anterior à história ao qual apenas um arqueólogo, em sua arqueologia da alienação, seria capaz de apreender. No segundo caso, o escopo era diferenciar duas formas de procedimento filosófico, a saber, a "linha divisória que separa uma filosofia da experiência, do sentido, do sujeito e uma filosofia do saber, da racionalidade e do conceito" (Foucault, 2000, p.353). Em outras palavras, o estudo da experiência, ou seja, da razão prática, implica algo distinto de um estudo propriamente epistemológico sobre a conceituação de tal razão, cujo exemplo marcante para Foucault foi Georges Canguilhem. ${ }^{3}$

Anos 90, Porto Alegre, v. 11, n. 19/20, p.101-138, jan./dez. 2004 
Nos vinte e três anos que separam os dois textos, é recorrente o uso do termo nos escritos de Foucault, fato que chamou a atenção de alguns comentadores. ${ }^{4}$ Não caberia aqui o levantamento minucioso das diversas acepções assumidas pela palavra experiência em tais escritos, tarefa que por si só se constituiria em uma pesquisa específica. Entretanto, não é custoso esboçar uma espécie de semântica histórica do conceito de experiência na obra do pensador francês. Se, a princípio, tal conceito aparece em uma obra realizada como um "estudo estrutural" do conjunto histórico compreendido pela experiência da loucura, ele remete a um campo de ação definido por estruturas que, na sua continuidade, antecedem a emergência de formas históricas dispersas, possibilitando a existência de figuras variadas da loucura. Tal concepção de experiência, ainda nos anos sessenta, passará por algumas transformações que modificarão essa espécie de continuidade fundamental, culminando na perspectiva descontinuísta apresentada em As palauras e as coisas, de 1966, onde a "experiência nua da ordem dos saberes" consiste em espaços díspares segundo o solo epistemológico do qual fazem parte (Foucault, 1995). Nesse sentido, ao invés de uma experiência fundamental em que se alojarão loucuras diferentes, o livro de 1966 apresenta, para a episteme de cada época determinada, uma experiência de saber diferente e singular, a qual origina formas de conhecimento diversificadas. ${ }^{5}$

De qualquer modo, a postura arqueológica assumida por Foucault admite a experiência como fundadora e condição da história. Ela se situa em uma posição dicotômica em relação à ciência, e, embora constituam referências mútuas - a experiência origina a ciência, que, por sua vez, possibilita novas experiências -, entre as duas há um espaço no qual se localiza o saber: "entre a ciência e a experiência há o saber: não absolutamente como mediação invisível, como intermediário secreto e cúmplice, entre duas distâncias tão difíceis ao mesmo tempo de reconciliar e de distinguir; de fato, o saber determina o espaço onde podem separar-se e situar-se, uma em relação à outra, a ciência e a experiência" (Foucault, 1999b, p.117). Essa concepção tem por característica principal, fato que gerou

Anos 90, Porto Alegre, v. 11, n. 19/20, p.101-138, jan./dez. 2004 
grande parte das polêmicas em torno da obra de Foucault, a ausência de um sujeito da experiência (Ternes, 2000, p.54-67). Há, anterior a ele, apenas um espaço no qual ele não passa de uma posição a ser assumida, localizada essa no interior de formações discursivas anônimas, destacadas das experiências subjetivas dos indivíduos, ainda que o próprio discurso seja visto como prática: "que não mais se relacione o discurso ao solo inicial de uma experiência nem à instância a priori de um conhecimento; mas que nele mesmo o interroguemos sobre as regras de sua formação" (Foucault, 1997, p.89).

Essa perspectiva, aos poucos, cederá lugar a um conceito de experiência histórica diferente, à medida que a análise arqueológica será complementada pela prática genealógica dos anos setenta. ${ }^{6}$ Nesse período, e seguindo até o momento derradeiro de sua obra, em 1984, experiência e subjetividade serão conceitos cada vez mais correlacionados. Próxima à idéia de uma atitude histórico-crítica a partir da qual um indivíduo relaciona-se consigo mesmo e com os outros, a experiência consistirá um espaço de ação no qual serão constituídos sujeitos históricos segundo processos definidos historicamente: "é a experiência que é a racionalização de um processo, ele próprio provisório, que termina num sujeito ou em vários sujeitos" (Foucault, 1984c, p.137). Muitos são os textos que remetem a essa questão e para esse uso do conceito de experiência; o estudo sobre o "uso dos prazeres" na Grécia clássica (Foucault, 1984a) é de particular importância para se tentar apreender o processo de configuração da ação mediante o uso do termo experiência como conceito operatório e articulador da narrativa. ${ }^{7}$

"Elas não deveriam ser uma história dos comportamentos nem uma história das representações". É dessa maneira que Michel Foucault (1984a, p.9) define, pela negativa, a série de pesquisas que pretendia tratar da sexualidade. Seu objetivo mais preciso é realizar uma história das problematizações ou uma história do pensamento acerca disso que hoje denominamos sexualidade. ${ }^{8}$ Assim, o espaço de ação do qual pretende dar conta restringe-se, no caso do texto em questão, ao mundo grego clássico, entre os séculos V e IV a.C.

Anos 90, Porto Alegre, v. 11, n. 19/20, p.101-138, jan./dez. 2004 
Seu projeto é bem definido: "uma história da sexualidade enquanto experiência - se entendermos por experiência a correlação, numa cultura, entre campos de saber, tipos de normatividade e formas de subjetividade" (Foucault, 1984a, p.10). Tratar-se-ia de um trabalho histórico-crítico sobre as relações que o indivíduo estabelece consigo mesmo através das quais ele se reconhece e se constitui como sujeito, levando em consideração os jogos de verdade dos quais faz parte. ${ }^{9}$ Em outras palavras, é o caso de uma genealogia do processo de subjetivação do indivíduo grego, considerando-o nos limites de uma moral dirigida para homens livres e que possuem certo status na sociedade. Seria, de fato, a história de uma experiência histórica: "o ser se constitui historicamente como experiência, isto é, como podendo e devendo ser pensado" (Foucault, 1984a, p.12).

O que hoje chamamos sexualidade foi problematizado, pelos gregos, como um campo moral particular, no qual estavam implicadas "técnicas de si" visando a uma "estética da existência". A questão era relativa à forma ideal de se conduzir no mundo quando os prazeres eram tematizados, assim como as regras de temperança que deveriam ser seguidas e os modelos de parcimônia que deveriam ser praticados, sendo as exigências de austeridade medidas segundo certos critérios de estilo em uma "arte da existência", que era tanto uma arte de governar os outros, no exercício de seu poder, como uma arte de governar a si mesmo, na prática da própria liberdade. O tema não se colocava da maneira como ocorreria pela experiência cristã da carne e mesmo pela experiência moderna da sexualidade, segundo parâmetros de proibições e permissões nos quais estariam assentados uma espécie de medo (em relação à masturbação), um esquema de comportamento (nos limites do matrimônio), uma imagem (o perfil da homossexualidade) e um modelo de abstenção (a castidade). Nesse sentido, Foucault adverte que foi levado a substituir "uma história dos sistemas de moral, feita a partir das interdições, por uma história das problematizações éticas, feita a partir das práticas de si" " (Foucault, 1984a, p.16). Assim, "era preciso pesquisar a partir de quais regiões da experiência, e sob que formas, o comportamento sexual foi problematizado, tornando-se objeto

Anos 90, Porto Alegre, v. 11, n. 19/20, p.101-138, jan./dez. 2004 
de cuidado, elemento para a reflexão, matéria para a estilização" (ibid., p.25).

Para a definição de tais "regiões da experiência", Foucault permite-nos pensar que os indivíduos, no processo de constituição de si mesmos enquanto sujeitos de uma experiência singular, encontram maneiras diferentes de se conduzir, ou seja, de agir em relação a um "código de ação" que define os contornos de uma experiência possível. No caso em particular do mundo grego, essa relação que, em outros termos, trata da dialética sujeito-estrutura constantemente tematizada pela reflexão teórica, é definida segundo certos critérios específicos. Em primeiro lugar, pela "determinação da substância ética", que procura circunscrever a parte do indivíduo que será objeto de sua conduta moral; em seguida, pelo "modo de sujeição" ou postura assumida em relação a uma regra, na obrigação de colocá-la em prática; em terceiro lugar, pela "elaboração de um trabalho ético", no qual o indivíduo é levado a se transformar em sujeito moral de sua conduta; por fim, por uma "teleologia do sujeito", pois "uma ação não é moral somente em si mesma e na sua singularidade; ela o é também por sua inserção e pelo lugar que ocupa no conjunto de uma conduta; ela é um elemento e um aspecto dessa conduta, e marca uma etapa em sua duração e um progresso eventual em sua continuidade" (Foucault, 1984a, p.28). Portanto, uma vez que "toda ação moral comporta uma relação ao real em que se efetua", o processo de subjetivação não se limita meramente a uma tomada de consciência de si segundo a fórmula cartesiana do cogito, mas também implica uma problematização do processo ao qual se é sujeitado: não é simplesmente a constatação do pensamento que garante a existência, mas também a necessidade de se problematizar aquilo sobre o que se pensa e mesmo sobre a forma como se pensa.

É, então, em torno de quatro temas que se problematiza a conduta dos indivíduos: a aphrodisia, ou os prazeres propriamente ditos; a chrësis, ou o uso dos prazeres; a enkrateia, ou a relação consigo e o domínio que se estabelece sobre si mesmo; e a söphrosunë, ou o estado de liberdade ao qual chega o indivíduo como sujeito em sua

Anos 90, Porto Alegre, v. 11, n. 19/20, p.101-138, jan./dez. 2004 
relação com a verdade. Quatro também são os modelos de ação ou "eixos da experiência" problematizados na cultura grega antiga: a dietética, que, tal como na alimentação, prevê regimes específicos para o controle dos excessos; a econômica, pautada pelo modelo privado da oikos, ou seja, da gerência matrimonial da casa, estendida ao ambiente público da administração da cidade; a erótica, a qual coloca como alvo do cuidado a relação com os rapazes, visto que, como foi dito, tratava-se de uma moral essencialmente masculina; e uma discussão em torno do verdadeiro amor, das possibilidades de acesso à verdade e de relações entre liberdade e amor.

Até aqui, como ficou evidente com a terminologia utilizada ("regiões da experiência", "eixos da experiência"), o que se sobressai é a composição de um campo onde uma ação torna-se possível. Trata-se de um campo moral, historicamente determinado, que define as possibilidades de condutas a serem praticadas pelos indivíduos no que diz respeito ao seu "uso dos prazeres". Dessa maneira, restaria a delimitação da dinâmica temporal ou, dito em outras palavras, do processo histórico que tornaria viável a tal campo de ação ser narrado, ou seja, a atribuição, através da narrativa, de um sentido para a experiência que nele toma lugar. No caso de Foucault, a experiência da sexualidade concerne ao processo de subjetivação dos indivíduos, isto é, à constituição de si como sujeitos de uma prática moral: uma experiência histórica é a ação de tornarse sujeito dessa experiência. Assim, antes de prosseguir nesta análise, é preciso apontar as características principais do sujeito histórico, segundo a perspectiva filosófica de Foucault.

A fim de se indicarem essas características do sujeito histórico, há que se considerá-lo nos seguintes termos. Antes de tudo, o sujeito é uma categoria histórica: a fragmentação do tempo praticada por Foucault em histórias descontínuas, como, por exemplo, em $A s$ palavras e as coisas, onde um corte definitivo entre espaços de saber é instaurado, teve por mérito mostrar a historicidade do pensamento sobre o homem e, conseqüentemente, do sujeito de conhecimento; afinal, em cada tempo distinto, se pensa o humano de uma maneira diferente. Em se tratando de discursos, o homem não lhes é soberano,

Anos 90, Porto Alegre, v. 11, n. 19/20, p.101-138, jan./dez. 2004 
mas apenas uma posição ocupada diante deles, a qual tem uma duração bastante restrita, como os próprios discursos. Condições que lhe são alheias dominam-no; ele é constituído por discursos e práticas sociais - "as condições políticas, econômicas de existência não são um véu ou um obstáculo para o sujeito de conhecimento mas aquilo através do que se formam os sujeitos de conhecimento e, por conseguinte, as relações de verdade" (Foucault, 1999a, p.27). A genealogia de Foucault descartava, pois, a figura do sujeito constituinte, recusava a idéia de encará-lo fora do campo de acontecimentos como que "perseguindo sua identidade vazia ao longo da história" (Foucault, 1998, p.7). Para o autor, o sujeito não é mais que um acontecimento historicamente datado com seu começo no já começado e seu sempre iminente momento derradeiro, o qual somente aparece no corpo social por meio de práticas de subjetivação. Disso decorre que é sempre uma forma de assujeitamento o que se realiza. Contudo, ela se apresenta sob duas perspectivas distintas e opostas: de um lado, o sujeitar-se ao outro sob coerção, por uma disputa de forças desiguais que não são exclusivamente de caráter físico; de outro, a escolha pessoal, a qual assume as vezes de escolha estética ou política, como discernimento de uma forma de existência. Lá, situa-se o caráter jurídico-moral de disciplinamento disciplinarização; aqui, as técnicas de si baseadas em uma estética ou estilística da existência.

A subjetivação, ou seja, o próprio sujeito, dá-se enquanto experiência, o que implica, por sua vez, o estabelecimento de relações de verdade. Isso equivale a dizer que não existe uma verdade essencial e interior inerente ao sujeito. Pelo contrário, entende uma verdade constituída por meio de regimes específicos, uma certa "'política' geral de verdade" (Foucault, 1998, p.12), ou seja, imposição e acatamento (ou oferta e acolhimento) de valores que definem o verdadeiro em relação ao falso, que legitimam discursos como verdadeiros, que autorizam determinados indivíduos a proferiremnos, que permitem certos procedimentos de obtenção da verdade etc. Por conseguinte, as relações estabelecidas são definidas por Foucault como "jogos de verdade", nos quais são evidenciadas "as 
formas e as modalidades da relação consigo através das quais o indivíduo se constitui e se reconhece como sujeito" (Foucault, 1984a, p.11).

Assim, percebe-se que se reconhecer como sujeito não significa reencontrar-se em uma identidade interior e anterior, situada em um lugar originário. Em outras palavras, quer se dizer que a subjetividade não é, de maneira alguma, uma categoria a priori, mas que o sujeito existe apenas na medida em que se constitui como tal. A experiência, por sua vez, traz em si mesma sua própria historicidade, os limites temporais que a delimitam. Ela não é colocada como que por sobre uma história que a perpassa anterior a ela e que definiria seu fim próximo; ela mesma é o começo e o fim de uma determinada história. Em uma expressão, experiência é a dupla construção, a de histórias pelos sujeitos, a dos sujeitos nas histórias.

Alguns dos comentadores que levaram em consideração o conceito de experiência em Foucault invariavelmente o identificam a esse processo de subjetivação. Entretanto, a perspectiva de seus comentários assimila, da maneira como não será aqui realizada, a obra a seu autor, isso é, trata-a como experiência realizada pelo próprio filósofo no sentido de desvelar novas formas de subjetividade para seu presente. A experiência que interessa neste estudo é particularmente a experiência grega da sexualidade, a reconstituição do espaço de ação onde os indivíduos gregos do sexo masculino e de determinada camada social podiam se constituir enquanto sujeitos morais no uso de seus prazeres e, especialmente, a temporalidade própria dessa ação. Antes, porém, de estabelecer as relações temporais da ação e o sentido da narrativa, convém analisar as características do conceito de experiência segundo a perspectiva de Thompson, uma vez que ela permitirá desenvolver mais detalhadamente as concepções aqui propostas. 


\section{Edward Palmer Thompson e a experiência da classe operária inglesa}

O livro A formação da classe operária inglesa (Thompson, 1987a) foi de início pensado, a pedido de um editor, como uma versão da história do movimento trabalhista britânico no período de 1832 a 1945. Recuando seu olhar em quase meio século, fato que, como se verá, é de capital importância para a sua concepção de experiência histórica, Thompson sequer conseguiu chegar ao ano de 1840, pois estabeleceu seu recorte entre as décadas de 1790 e 1830, escrevendo, apenas sobre esse período, quase um milhar de páginas pouco convencionais se forem levados em consideração os parâmetros acadêmicos. $\mathrm{O}$ próprio autor considerou seu trabalho um tanto inocente quanto às exigências de adequação para um público especificamente universitário. Em relação à sua nítida e por vezes extravagante tomada de posição, dissonante em relação à proclamada austeridade científica da academia, afirmou categoricamente: "a história é a memória de uma cultura e a memória jamais pode estar livre de paixões e de comprometimentos. Não me sinto inibido de forma nenhuma pelo fato de que minhas próprias paixões e comprometimentos sejam evidentes" (apud Palmer, 1996, p.123124). ${ }^{10}$ Não obstante o distanciamento de seu autor em relação à universidade, é inegável a importância que teve o livro nos caminhos e descaminhos da historiografia acadêmica do século XX, quer seja por questões teórico-metodológicas gerais, quer seja por questões especificamente internas ao marxismo, ao materialismo histórico, à história socialista ou à história social. ${ }^{11}$

Saliente-se ainda o fato de que, muito festejada, a escrita historiográfica de Thompson nem sempre é objeto de considerações mais cuidadosas e detalhadas. Segundo Hobsbawm (2001, p.15), Thompson, presenteado pela "dádiva da escrita", era escritor "da mais fina e polêmica prosa do século XX". Perry Anderson, em uma discreta ironia, sugere que, antes de importantes escritos de história, A formação da classe operária inglesa (Thompson, 1987a) e Senhores e caçadores (Thompson, 1987b) são, sobretudo, "grandes obras de literatura" (Anderson, 1985, p.1). Edgar Salvadori de Decca, por

Anos 90, Porto Alegre, v. 11, n. 19/20, p.101-138, jan./dez. 2004 
sua vez, comenta que "o ponto central do pensamento radical, quer dizer, do ser radical, dissidente e libertário (exemplificado por Thompson) é, antes de tudo, ter a paixão pela palavra, a paixão pelo discurso". Ele vai ainda mais longe e enfatiza o papel preponderante da narrativa thompsoniana: "a narrativa é tudo, a narrativa é que constrói o objeto histórico, é o modo pelo qual o discurso historiográfico se constitui enquanto lógica, enquanto coerência para que determinadas bases factuais sejam legitimadas" (de Decca, 1995, p.15 e 17). A parte mais interessada nesta última colocação, isto é, o próprio Thompson, talvez tivesse algumas ressalvas a fazer quanto a tal afirmação.

Assim, entre a prosa e a literatura, passando pelo caráter instituidor de sua narrativa, a escrita da história tal como praticada pelo autor de $A$ formação da classe operária inglesa é objeto de comentários que, em alguns casos, acabam por contradizer nitidamente a postura teórica do próprio autor (o que não é por si só uma falha), mas cujo teor nem sempre ultrapassa a simples impressão estética. Nesse sentido, um olhar mais detido sobre essa prática, centrado principalmente na superfície do texto tomado como paradigma de análise, ${ }^{12}$ pode apresentar detalhes mais interessantes ao leitor que o simples louvor, a fina ironia ou o inflamado panegírico. Para tanto, propõe-se aqui um desvio em relação às próprias intenções de Thompson, que considerava seu livro sobretudo como "um conjunto de estudos sobre temas correlatos" e não tanto "uma narrativa seqüenciada" (Thompson, 1987a, v.I, p.12). Ou seja, a proposta que se segue é tratá-lo justamente enquanto uma narrativa de um fenômeno histórico singular, isto é, a formação de uma classe operária em determinado espaço de ação e num prazo de tempo definido.

De início, destaca-se o caráter ativo do processo em questão, o fazer-se da classe operária inglesa. Thompson aponta para a noção de making enquanto um fenômeno que remete "tanto à ação humana como aos condicionamentos", salientando que a classe em questão "estava presente ao seu próprio fazer-se". Trata-se de um fenômeno histórico no qual convergem acontecimentos díspares "tanto na

Anos 90, Porto Alegre, v. 11, n. 19/20, p.101-138, jan./dez. 2004 
matéria-prima da experiência como na consciência", fenômeno tal que aponta para uma característica fundamental: classe não é um objeto dado de antemão, mas uma relação que se constrói na medida de sua construção (Thompson, 1987a, v.I, p.9). ${ }^{13}$ Para o autor, a existência concreta de uma classe evidencia-se pela identidade de interesses e valores, partilhados por indivíduos segundo uma experiência em comum, que se contrapõem a interesses e valores de outros indivíduos que partilham uma experiência diversa e que, de modo semelhante, constituem uma classe antagônica. ${ }^{14}$ Dois são os termos-chave nessa noção: de um lado, tem-se a experiência de classe, em grande medida determinada pelas relações de produção nas quais os indivíduos são involuntariamente inseridos; de outro, tem-se a consciência de classe, que se refere ao trato cultural da experiência ("tradições, sistemas de valores, idéias e formas institucionais"). Se a primeira é determinada, a segunda pode-se dizer determinante, pois orienta o sentido das ações realizadas. Nessa direção, "podemos ver uma lógica nas reações de grupos profissionais semelhantes que vivem experiências parecidas, mas não podemos predicar nenhuma lę" (Thompson, 1987a, v.I, p.10).

Percebe-se que aqui o conceito de experiencia desponta como um espaço, definido segundo relações produtivas específicas, no qual ações conscientes tomam lugar e são praticadas. Nesse caso, é a ação de constituição de uma classe que aparece como experiência: "a classe é definida pelos homens enquanto vivem sua própria história e, ao final, esta é sua única definição" (ibid., p.12). ${ }^{15}$ Em decorrência dessa concepção, para Thompson é impossível vislumbrar-se uma classe em um recorte sincrônico, onde, segundo ele, há simplesmente "uma multidão de indivíduos com um a montoado de experiências"; por outro lado, em um "período adequado de mudanças", ou seja, na diacronia, observam-se padrões e regularidades nas ações que implicam, como foi visto, menos leis do que uma lógica histórica própria: "não podemos entender a classe a menos que a vejamos como uma formação social e cultural, surgindo de processos que só podem ser estudados quando eles mesmos operam durante um considerável período histórico" (idem). ${ }^{16}$ 
Assim, semelhante à noção apresentada por Foucault, a experiência histórica em A formação da classe operária inglesa trata, de maneira geral, do processo histórico segundo o qual se elabora um espaço de ação onde se constitui um sujeito da experiência. ${ }^{17} \mathrm{O}$ historiador inglês, na narrativa de tal fenômeno, retorna à última década do século XVIII, momento em que não havia ainda uma classe definida pela consciência que lhe assegurasse uma identidade histórica, para reconstituir, ao longo do texto, o conjunto de "tradições persistentes" que propiciaram o campo de possibilidade para a formação da classe operária inglesa: a tradição da Dissidência influenciada pelo metodismo; a tradição nacional em torno da noção de liberdade (o "inglês livre de nascimento"); e a tradição popular de manifestação do século XVIII (a "turba"), que mais tarde seria definida detalhadamente pelo autor como "economia moral da multidão". ${ }^{18}$

A persistência de uma espécie de "radicalismo adormecido" do século XVIII, eventualmente reavivado durante o XIX, aliou-se ao "quietismo político" de seitas religiosas dissidentes que dirigiam sua expectativa e o consolo compensatório das injustiças terrenas para uma vida no além. Entretanto, salienta Thompson, a Dissidência, enquanto oposição à Igreja Anglicana oficial, fortemente inspirada no fervor do jacobinismo inglês do momento, apesar de sua rigidez disciplinar e de um certo intelectualismo que diminuía sua capacidade de atração popular, encontrou solo propício no descontentamento de camadas sociais desfavorecidas: "a história intelectual da Dissidência é composta de choques, cismas, mutações; muitas vezes sentem-se nela os germes adormecidos do radicalismo político, prontos para germinar logo que semeados num contexto social promissor e favorável" (Thompson, 1987a, v.I, p.36).$^{19}$ Dessa maneira, a ação dissidente foi pelo autor definida como "viveiro para as variantes da cultura operária do século XIX" (ibid., p.52).

No conjunto das tradições em que se insere a Dissidência, Thompson localiza ainda duas outras tradições definidas como "subpolíticas": "os fenômenos do motim e da turba e as noções populares de um 'direito de nascimento' do inglês" (ibid., p.62).

Anos 90, Porto Alegre, v. 11, n. 19/20, p.101-138, jan./dez. 2004 
No primeiro desses fenômenos, está implícita uma distinção entre código legal e código popular, a qual orienta a dinâmica do conflito social em torno da noção de propriedade: de um lado o aparato jurídico instituído, de outro a prática de um direito consuetudinário. Além disso, os motins originavam-se também de um descontentamento mensurável, por exemplo, pela alta no preço do pão. Esses distúrbios sociais por causa de alimentos constituíamse como ações populares legitimadas por uma "antiga economia moral paternalista": segundo o autor, "ações de tal envergadura indicam um modelo de comportamento e crença com raízes extraordinariamente profundas" (Thompson, 1987a, v.I, p.69). Entre tais movimentos, a turba londrina de finais do século XVIII desponta, no olhar de Thompson, como uma turba em transição, quase como uma "multidão radical autoconsciente" em vias de se reconhecer como classe. ${ }^{21}$

Outra tradição que expandiu o universo da cultura popular, possibilitando a formação da classe operária na Inglaterra, foi a que remetia às noções de patriotismo e independência expressas pela fórmula do "direito de nascimento", alimentando a idéia de liberdade individual no ideário político inglês. Segundo Thompson, essa "retórica da liberdade" transcendia os limites da segurança de propriedade e englobava muitas outras manifestações que, no conjunto, refletiam um certo consenso moral compartilhado até mesmo pelas autoridades. O indivíduo, "livre por nascimento", aparecia como valor que desempenhava o papel de contraponto à centralização estatal; para o historiador inglês, "nessa hostilidade ao aumento dos poderes de qualquer autoridade centralizada, temos uma curiosa mescla de atitude paroquial defensiva, teoria liberal e resistência popular" (Thompson, 1987a, v.I, p.89). Além da liberdade e da segurança do indivíduo em relação a qualquer arbítrio ou ingerência do Estado, havia uma tradição marcada por idéias igualitárias; sua expressão maior estava no escrito de Thomas Paine, Os direitos do homem, para Thompson "uma nova retórica do igualitarismo radical, que afetou as reações mais profundas do 'inglês livre de nascimento' e penetrou nas atitudes subpolíticas do operariado urbano" (ibid., p.102).

Anos 90, Porto Alegre, v. 11, n. 19/20, p.101-138, jan./dez. 2004 
$\mathrm{Na}$ descrição de tais tradições, Thompson desenvolveu um percurso que lhe permitiria, no decorrer da narrativa, reconstituir o fenômeno histórico marcado pela experiência de formação da classe operária inglesa e a simultânea constituição da consciência de classe. Opção de método e postura teórica: segundo ele, tratava-se de derrubar as "muralhas da China" que separavam, no conjunto da historiografia tradicional, o século XVIII e XIX. Com essa derrubada, estabelece-se uma ligação marcada pela convergência entre "a história da agitação operária e a história cultural e intelectual do resto da nação" (ibid., p.111). Trata-se de uma relação também temporal, uma vez que insere determinada experiência - a constituição de uma classe - em um estrato de tempo que a determina mas também a ultrapassa, já por ela modificada: um espaço de ação (não apenas de possibilidades discursivas) no qual um sujeito, atuando e constituindo-se nesse atuar, expande as perspectivas do sentido da experiência. Se as tradições definem tal espaço pela dinâmica temporal que elas mesmas alimentam, ele é simultaneamente delimitado de acordo com um modelo estrutural das relações de produção. ${ }^{22}$

Thompson destaca mais de cem páginas para discorrer sobre modos de exploração no antagonismo das classes e a correlata deterioração das condições de vida dos trabalhadores. Recusa uma versão tradicional do tema, segundo a qual a classe operária seria meramente um produto de uma equação economicista na qual as variantes principais seriam a energia do vapor e a indústria algodoeira. Em suas palavras, "não podemos assumir qualquer correspondência automática ou excessivamente direta entre a dinâmica do crescimento econômico e a dinâmica da vida social ou cultural" (Thompson, 1987a, v.II, p.69). ${ }^{23}$ As transformações por que passou a indústria de algodão, por exemplo, das manufaturas artesanais para o tear mecânico, ainda que com importantes implicações no desenvolver do processo, não podem ser consideradas como razão elementar do fenômeno, pois tal posicionamento tende a desconsiderar, ou a relegar ao âmbito redutor da dicotomia "base/superestrutura" (Wood, 2003, p.51-72), a persistência de tradições políticas e culturais nas

Anos 90, Porto Alegre, v. 11, n. 19/20, p.101-138, jan./dez. 2004 
comunidades trabalhadoras; "os operários longe de serem "filhos primogênitos da revolução industrial', tiveram nascimento tardio" (Thompson, 1987a, v.II, p.16). ${ }^{24}$

Thompson coloca em jogo, dessa maneira, a relação entre experiência e consciência, uma vez que, instituindo um termo singular (classe) ao invés do plural que mantém as diferenças e polissemias internas das "classes", defende que, pelo crescimento da consciência de classe e das formas correspondentes de organização e atuação políticas, é possível homogeneizar as diferentes categorias englobando-as sob um conceito singular: "classe". ${ }^{25}$ Daí que, em três capítulos subseqüentes, analisa as condições de vida, vale dizer, as experiências de três categorias variadas: trabalhadores rurais, "artesãos e outros" e tecelões. Para o autor, tratava-se de uma perspectiva teórica precisa que procuraria retomar "o sentido global do processo", sentido esse marcado não só pela nitidez da exploração econômica e opressão política, mas também pela contribuição à "coesão social e cultural do explorado", favorecida ambiguamente pelo metodismo, que servia também como disciplina social, e pela noção de comunitarismo, marcadamente as sociedades de auxílio mútuo.

O que se sucede na narrativa, então, é a atuação própria dos trabalhadores no processo em direção a uma consciência de classe "plenamente" constituída, através da descrição empírica de momentos significativos para os argumentos do autor: as vitórias eleitorais em Westminster, ao sul da Inglaterra, na primeira década do século XIX, favoráveis aos trabalhadores e que funcionaram como "válvula de escape" democrática para o descontentamento popular; o retraimento por conta das medidas jurídicas tomadas pelas autoridades no sentido de proibir as associações de cunho operário; o movimento luddista em diversas localidades, cujas práticas eram encaradas como manifestação da cultura operária, opondo o direito oriundo dos costumes às prerrogativas da legislação estatal; e o impacto, traumático para ingleses "livres de nascimento", do massacre de Peterloo, no qual uma manifestação pública foi duramente rechaçada pela polícia montada, ocasionando diversas mortes de manifestantes.

Anos 90, Porto Alegre, v. 11, n. 19/20, p.101-138, jan./dez. 2004 


\section{Fernando Nicolazzi}

Todos esses fatores, para Thompson, contribuíram para o processo de formação de uma classe operária consciente de sua identidade histórica. No ambiente de diversos conflitos convergentes (a luta pela liberdade de imprensa, aumento da força sindical, revogação das Leis de Associação, crescimento do livre pensamento, expansão das cooperativas), formou-se o solo propício para germinar uma consciência proveniente da dupla experiência da Revolução Industrial e do radicalismo popular: partiu-se da prática radical a uma cultura política conscientemente articulada e fez-se valer o autodidatismo dos trabalhadores que, "a partir de sua experiência própria e com o recurso à sua instrução errante e arduamente obtida [...] formaram um quadro fundamentalmente político da organização da sociedade" (Thompson, 1987a, v.III, p.304) - a classe formandose a si mesma.

Nesse período que segue da última década do século XVIII até as três primeiras do XIX, Thompson estabelece o espaço no qual uma ação tomou lugar: a experiência histórica da formação da classe operária inglesa. Evidenciada nos discursos que, a partir de então, assumiam um "nós" coletivo e nos quais o autor percebe a maturidade do movimento operário, ${ }^{26}$ a classe operária inglesa, plenamente consciente de seus próprios interesses e valores, em 1832, "não está mais no seu fazer-se, mas já foi feita", e a "presença operária pode ser sentida em todos os condados da Inglaterra e na maioria dos âmbitos da vida", se não por outros fatores, mas pela própria luta de classes (Thompson, 1987a, v.III, p.411). Com esse ensejo, é encerrada também a narrativa de tal experiência.

Ainda que se incorra na desproporção de espaço concedido aos dois autores em pauta, é preciso deter-se um pouco mais em uma questão-chave na obra de Thompson, visto que ela foi objeto de inúmeras e pertinentes discussões, fato que não ocorreu (ainda) com o mesmo vigor em relação aos escritos de Foucault. Dos lucros e das despesas oriundos desse seu primeiro grande livro, Thompson guardou, no decorrer da sua carreira, um que certamente encontrase entre os principais: o conceito de experiência. Se lucro ou despesa, não se sabe ao certo.

Anos 90, Porto Alegre, v. 11, n. 19/20, p.101-138, jan./dez. 2004 
Dois anos após a publicação de $A$ formação da classe operária inglesa, em uma das suas primeiras grandes polêmicas no interior da historiografia marxista, Thompson aponta algumas questões conceituais a serem discutidas pelo materialismo histórico. Salientando a importância do uso de modelos analíticos no estudo de processos históricos, o autor defende a necessidade da concepção de modelos que permitam trabalhar com a autonomia da consciência em frente às determinações do ser social. ${ }^{27}$ Para Thompson, enfático nessa questão, "sem cultura não há produção"; a cultura determina o processo histórico tanto quanto a economia e, a partir dessa concepção, a luta de classes é, ao mesmo tempo, uma luta de interesses e valores elaborados culturalmente: ${ }^{28}$

[...] o que muda, assim que o modo de produção e as relações produtivas mudam, é a experiência de homens e mulheres existentes [...] a transformação histórica acontece não por uma dada "base" ter dado vida a uma 'superestrutura' correspondente, mas pelo fato de as alterações nas relações produtivas serem vivenciadas na vida social e cultural, de repercutirem nas idéias e valores humanos e de serem questionadas nas ações e crenças humanas (Thompson, 2001, p.260-262).

Surge daí o papel central assumido pelo conceito de experiência na obra do historiador inglês, qual seja, desempenhar um papel mediador entre a consciência social e o ser social. ${ }^{29} \mathrm{Em}$ sua famosa polêmica contra Louis Althusser, publicada em 1978 com o título de A miséria da teoria (Thompson, 1981), destacam-se pontos capitais sobre epistemologia da história tais como entendidos e praticados por Thompson. Para este, sem meias palavras, "a experiência não espera discretamente, fora de seus gabinetes, o momento em que o discurso da demonstração convocará a sua presença. A experiência entra sem bater à porta e anuncia mortes, crises de subsistência, guerra de trincheiras, desemprego, inflação, genocídio" (ibid., p.17). Ela se caracteriza pelas pressões do ser social

Anos 90, Porto Alegre, v. 11, n. 19/20, p.101-138, jan./dez. 2004 


\section{Fernando Nicolazzi}

sobre a consciência social e também aparece como resposta mental e emocional dos indivíduos ou grupos sociais em determinados acontecimentos. ${ }^{30}$ Para o autor, a relação entre a história, enquanto fluxo de tempo, e o indivíduo, em sua finitude temporal, dá-se pela experiência, que surge espontaneamente no ser social, mas isso apenas se dá quando esse ser é pensado: "assim como o ser é pensado, também o pensamento é vivido” (id.).

Thompson considera o âmbito da cultura como lugar primeiro da experiência, uma vez que esta "dá cor à cultura". Assim, salienta que a experiência é um dos "silêncios de Marx", bem como o "termo ausente" no "planetário" de Althusser: naquele, a ênfase recai nas determinações de base econômica da infraestrutura; neste, a teoria sobrepõe-se ao mundo empírico. Contudo, Thompson permanece no âmbito do materialismo histórico, reinventando-o e rejeitando veementemente a alcunha de "culturalista", pois acredita que a experiência é sempre gerada na vida material, sob a pressão determinante do modo de produção sobre a consciência dos indivíduos. Seu interesse é ressaltar a agência humana no processo histórico, apontando para um retorno do sujeito da experiência, "não como sujeitos autônomos, 'indivíduos livre', mas como pessoas que experimentam suas situações e relações produtivas determinadas como necessidades e interesses e como antagonismos, e em seguida 'tratam' essa experiência em sua consciência e sua cultura das mais complexas maneiras e em seguida agem, por sua vez, sobre sua situação determinada" (Thompson, 1981, p.182). Portanto, ao invés de um processo previsível no qual os fenômenos se ligariam por causalidades mecânicas, Thompson retoma a imprevisibilidade da ação humana, na manipulação pelos indivíduos de sua própria experiência.

Essa imprevisibilidade não implica uma recusa da racionalidade do processo, o que é por Thompson definido como "status ontológico do passado". Como o autor já havia salientado em $A$ formação da classe operária inglesa, não se trata de leis regendo a história, mas de uma lógica construída mediante a significação do processo; para ele, seria possível medir-se, pela relação entre ser e

Anos 90, Porto Alegre, v. 11, n. 19/20, p.101-138, jan./dez. 2004 
consciência, a amplitude das ações possíveis em um definido contexto, embora seu sentido permaneça para além das predeterminações. Uma crítica pertinente a tal concepção foi formulada por Perry Anderson, que considera problemática a ligação tão direta entre ação e consciência. Para este, há setores na história em que a ação não incide socialmente de maneira voluntária ou consciente, como as análises demográficas e os estudos sobre a língua podem comprovar; neste caso, a consciência do ato (de reproduzir-se ou de falar) está inserida em um conjunto de determinações que transcendem o controle dos indivíduos. Em A formação..., por exemplo, "a forma fundamental que tomou esta ação foi a conversão de uma experiência coletiva em uma consciência social que, assim, definiu e criou por si mesma a classe" (Anderson, 1985, p.32). Com isso, conclui ele, o peso elevado da consciência na ação acaba por tornar esta uma refém na obra de Thompson, com um papel "ajustado ad hoc" para encaixar-se em determinados propósitos. Constantemente procurado no livro, o papel da ação segue nele sendo esquivo.

Se, para Thompson, a experiência é o mediador entre ser social e consciência, para Anderson, essa mediação não é de todo evidente e, em alguns casos, deixa de existir pela pressão absoluta do ser sobre a consciência. William Sewell Jr., por sua vez, acredita que experiência é o conceito-chave da "estratégia narrativa" de Thompson, o qual não pode desempenhar um papel mediador justamente pelo fato de a formação da classe ser ela mesma uma experiência. O que poderia aparecer como paradoxo impulsiona o olhar para outra direção do debate. Ao invés de aprofundar a discussão das relações entre ser e consciência, Sewell Jr. sugere que o verdadeiro sentido do conceito de experiência como medium é menos a mediação entre dois elementos e mais o espaço em que as ações tomam lugar e realizamse: "as relações de classe tacitamente colocadas como presentes na base material, são realizadas no meio (medium) da experiência humana [...] uma estrutura sincrônica tacitamente colocada realizase a si mesma nas vidas reais, históricas e experienciadas dos atores humanos" (Sewell Jr., 1990, p.60). Aquilo que não poderia ser explicado por determinações infra-estruturais seria deslocado para

Anos 90, Porto Alegre, v. 11, n. 19/20, p.101-138, jan./dez. 2004 
o âmbito da experiência, esta "categoria residual" que concerne às "profundas complexidades da existência humana" e à "operação imprevisível da agência humana" (ibid., p.62-63).

Talvez "categoria residual", pelo seu papel central no debate, não seja um termo de todo adequado para definir o conceito de experiência em Thompson, mas é possível seguir-se a linha de raciocínio de Sewell Jr. deixando-se de lado o debate tal como conduzido por Anderson. Ao invés de se perceber a experiência apenas por meio da dicotomia ser/consciência, é possível considerála, no interior da narrativa como conceito que estabelece um espaço de ação determinado por relações estruturais de produção, no qual a consciência encontra o meio (medium) para se constituir autonomamente e, por conseqüência, ser determinante no modo como tais relações são vivenciadas. É a experiência como ação que se tematiza, não apenas como relação, e, enquanto tal, é a dinâmica da ação que interessa discutir tendo por pano de fundo as convergências entre o tempo da narrativa da experiência bem como o tempo da experiência narrada. Vejamos, portanto, em que medida é possível trabalhar-se com o conceito da maneira como desenvolvido por Foucault e Thompson.

\section{A experiência histórica}

Encontrar-se uma maneira de trabalhar o mesmo conceito utilizando-se autores oriundos de tradições tão díspares e antagônicas não é das coisas mais simples. Como aponta Durval Muniz de Albuquerque Junior, em artigo que tem por tema justamente o conceito de experiência em Thompson e Foucault, esses dois autores partem de pressupostos teóricos tais, cuja distinção torna inconciliável um ao outro (Albuquerque Jr., 2002, p.61-75). Ambos definem a história a partir de duas diferentes perspectivas, denominadas pelo autor como "realismo" e "nominalismo". $\mathrm{Na}$ primeira, notadamente a de Thompson, Albuquerque sugere que o que se defende são essências, totalidades, a verdade na razão e uma

Anos 90, Porto Alegre, v. 11, n. 19/20, p.101-138, jan./dez. 2004 
experiência unitária; a realidade existe anterior à linguagem, e a experiência distingue-se da consciência como uma empiria anterior, caracterizando-se como o lugar por excelência do ser. A outra, propriamente de Foucault, é apresentada pelo autor como dispersão das totalidades, como polissemia da verdade, pela crítica da razão e pela fragmentação da experiência; realidade e linguagem condicionam-se mutuamente, não havendo um a priori do discurso: na experiência, o ser e a consciência são inseparáveis.

Parece-me, contudo, que, neste caso, se trata da experiência muito mais como uma idéia norteadora de determinada postura epistemológica (para Thompson, história como estudo das semelhanças; para Foucault, como estudo das diferenças) do que precisamente, tal como se entende aqui, como conceito inserido em uma narrativa, utilizado para garantir a dinâmica temporal de um definido processo. Essa é uma sutileza teórica que sugere certo desvio em relação a grandes generalizações. Tomando-se a experiência como conceito que tem por escopo estabelecer uma referência empírica na ordem temporal de determinado fenômeno, pode ser possível realizar-se essa reflexão no ponto de cruzamento dos textos de tais autores. Como se buscou evidenciar, tanto na história da sexualidade grega quanto na da classe operária inglesa, a experiência diz respeito a um processo no qual, segundo condições tais, dá-se um fenômeno cuja construção é simultânea à constituição daquele que age enquanto sujeito. No que é tido como óbvio, esse é o dado prévio fundamental: a experiência histórica refere-se à experiência de um sujeito da história. Alterando-se o foco, é possível inseriremse alguns outros dados nesse problema, abstraindo-se sua evidente obviedade: experiência e subjetividade tornam-se mais compreensíveis quando relacionadas com duas outras categorias, quais sejam, ação e tempo. O resultado é o enlace entre um sujeito da ação e sua experiência de tempo.

Tanto Thompson como Foucault estabelecem o conceito de experiência como espaço onde uma ação desenvolve-se segundo articulações de tempo distintas. A formação da classe operária inglesa é uma ação na qual se privilegia o "espaço de experiência" de seu

Anos 90, Porto Alegre, v. 11, n. 19/20, p.101-138, jan./dez. 2004 
sujeito, enquanto que a constituição do sujeito moral grego (na perspectiva do que consideramos como sexualidade) é uma ação orientada preponderantemente em direção a um "horizonte de expectativa". "Tais argumentos talvez se tornem evidenciados se o olhar incidir sobre o texto narrativo.

A primeira parte de $A$ formação da classe operária inglesa é destinada à reconstituição do que Thompson definiu como "tradições persistentes", cujos germes adormecidos desabrochariam segundo condições favoráveis. Tais tradições criariam as circunstâncias propícias para a formação de uma classe operária, não apenas enquanto fator do modo de produção, mas segundo um grau elevado de consciência que gerasse sua identidade histórica própria. Nesse processo, o conflito de interesses visto sob a perspectiva cultural surge como conflito por temporalidades diferentes; a luta de classes, entendida como luta de valores, encontra expressão em dois elementos contraditórios entre os quais o tempo sofre a tensão de direções opostas: o retorno ao anterior dos valores consuetudinários das camadas de trabalhadores e o agora em diante do modelo progressivo de uma classe capitalista.

Referente a tais tradições, o autor salienta um princípio "subpolítico" que aparece em alguns momentos específicos: na defesa irredutível das aspirações liberais do indivíduo representado pela noção de "inglês livre de nascimento", bem como a idéia de patriotismo, pela qual havia a crença em um "lugar original"; na economia moral legitimando formas de ação espontânea na segundo metade do século XVIII, momento em que, segundo Thompson, tornou-se mais aguda a distinção entre um código popular nãoescrito em processo de deterioração em prol de um código legal oficializado; nos motins resultantes da alta no preço dos alimentos ou mesmo da perda de espaços de sociabilidade como as feiras livres, nas quais vigoravam certos costumes de preço-justo, em oposição à especulação do livre mercado, e que, para o historiador, indicavam um comportamento com raízes bastante profundas da cultura popular. Aquilo que Thompson qualifica como "subpolítico" está inserido em um plano de sucessão: o prefixo, no caso, remete a

Anos 90, Porto Alegre, v. 11, n. 19/20, p.101-138, jan./dez. 2004 
certa anterioridade de uma ação, que é muito mais uma escala de tempo que uma hierarquia de valores; o subpolítico não está abaixo do político, ele é o que precede este.

A experiência de formação da classe é compreendida como um "espaço de experiência” em que, na pressão exercida pelo passado sobre o presente, é criada a condição histórica da classe operária. Entre tais indivíduos, saliente-se a presença de "homens que nutrem ressentimentos pelos direitos perdidos e apresentam as resistências inerentes ao 'inglês que nasceu livre"' (Thompson, 1987a, v.II, p.57). A destruição de padrões de vida impulsionava seu anseio pelo retorno a certos modelos ancestrais, explícitos nas palavras do líder cartista Feargus O'Connor, que dão mostras do que Thompson chamou de "mito social da idade de ouro da vila comunitária anterior aos cercamentos e às Guerras": "que possamos viver para assistir à restauração dos velhos tempos na Inglaterra, das velhas tradições inglesas, dos antigos dias santos, da antiga justiça, e que cada homem viva do suor do seu rosto [...]" (apud Thompson, op. cit., p.65). Entre os tecelões do norte, por exemplo, "as recordações do status perdido fundamentava-se em experiências reais e de longa duração", permeadas pela "lenda de um passado melhor" (ibid., p.120).

O que se evidencia é que a consciência que se constituía no processo era também uma consciência de tempo, de um rumo e de um ritmo temporais contra a qual seria possível imporem-se experiências outras, pautadas por temporalidades diferentes, com seus valores agregados fundados segundo padrões diversos. Nesse ponto, momento de transição entre duas formas de vida social, às tradições dissidentes apresentadas na primeira parte do livro juntaram-se modelos de exploração que marcavam as condições de vida dos trabalhadores, descritas na segunda parte. A consciência de classe em formação era também uma forma de resistência; "tratavase de uma resistência consciente ao desaparecimento de um antigo modo de vida, freqüentemente associada ao radicalismo político" (ibid., p.300). O desaparecimento da "velha Inglaterra" acompanhava-se de uma classe nova que se fazia surgir. 
As atividades luddistas expostas na terceira parte do livro seguem, em grande medida, uma tal consciência. O radicalismo, nas suas condutas, apontava para um "conflito de transição", pois, "de um lado, olhava para trás, para costumes antigos e uma legislação paternalista que nunca poderiam ressuscitar; de outro lado, tentava reviver antigos direitos a fim de abrir novos precedentes" (Thompson, 1987a, v.III, p.123). A isso se soma a função de amálgama desempenhada pelo metodismo no sentido de um espaço comum para o sentimento de pertencimento a determinado grupo, além da capacidade de organização institucional desse grupo. Evidenciavase ainda mais a consciência de classe pela formação de um instrumental discursivo pertinente, destacando-se aqui a apropriação pelos trabalhadores das idéias owenistas. Dentro de tal movimento, variadas tendências eram assumidas e, para uma parte do grupo de trabalhadores, os "qualificados", "o movimento que começara a tomar forma em 1830 finalmente parecia dar corpo a sua aspiração há tanto tempo alimentada - uma união nacional geral" (ibid., p.399).

Em 1832, portanto, segundo o espaço de experiência que a tornou possível, a classe operária inglesa chegava finalmente ao seu "presente", e sua presença, para Thompson, era já sentida por toda parte. Nesse caso específico, as pressões do passado orientam a ação; o passado-presente define a possibilidade de uma história e, da mesma maneira, determina também suas condições de representação, isto é, sua forma narrativa.

A experiência da sexualidade grega estabelece uma dinâmica através da qual é o "horizonte de expectativa" do sujeito que a experiencia aquilo o que define o sentido temporal da ação empreendida. A problematização dos prazeres, da forma como Foucault a realiza, instaura o recorte de diversos "eixos da experiência", por meio dos quais, segundo condições específicas, o indivíduo reconhece-se como sujeito, isto é, ele se pensa através de um conjunto de valores definidos como uma estética da existência. "É verdade que toda ação moral comporta uma relação ao real em que se efetua, e uma relação ao código a que se refere; mas ela implica também uma certa relação a si; essa relação não é simplesmente 
'consciência de si', mas constituição de si enquanto 'sujeito moral"' (Foucault, 1984a, p.28). Daí que a agência humana é também tematizada por Foucault, na medida em que ele estabelece a distinção entre elementos do código moral e elementos da ascese pessoal. A relação entre ambos determina o grau de autonomia desenvolvida pelo sujeito da ação relativamente ao seu campo de atuação.

As regras de temperança que definem o "uso dos prazeres" têm por escopo fundamental a longevidade que se apresenta sob dois aspectos: de um lado, o prolongamento da vida singular do indivíduo e, de outro, a perpetuação coletiva da espécie. No primeiro caso, a finitude de tempo, ou seja, a duração, encontra-se recortada pelos limites do corpo e, no segundo caso, ela é estabelecida pelo período da vida. O uso adequado dos prazeres garante a energia do corpo e a reprodução da vida. A relação de si do sujeito é, em razão disso, tomada em dois níveis: uma relação consigo mesmo e uma relação social com o grupo. Em Platão, por exemplo, desenvolve-se um modelo cívico de moderação, sendo que "nele a ética dos prazeres é da mesma ordem que a estrutura política" (ibid., p.67). O "horizonte de expectativa" que se abre segundo os modelos dessa estética da vida visa a um estado de liberdade em conformidade com a verdade da razão (logos), não entendida como livre-arbítrio, mas como oposta à servidão; trata-se de uma liberdade ativa do sujeito, "indissociável de uma relação estrutural, instrumental e ontológica com a verdade" (ibid. p.84). A ética dos aphrodisia sustenta o domínio de si mesmo, em contraposição à escravidão das próprias paixões, e sustenta também uma idéia de sociedade não regida pelo desmedido poder do tirano, mas pelo controlável exercício do chefe.

O que se sobressai disso tudo é um ideal de vida bastante singular. "Pelo logos, pela razão e pela relação com o verdadeiro que a governa, uma tal vida inscreve-se na manutenção ou reprodução de uma ordem ontológica; e, por outro lado, recebe o brilho de uma beleza manifesta aos olhos daqueles que podem contemplá-la ou guardá-la na memória” (ibid., p.82). Mais adiante, Foucault acrescenta: "o indivíduo se realiza como sujeito moral na plástica de uma conduta medida com exatidão, bem visível de todos e digna de

Anos 90, Porto Alegre, v. 11, n. 19/20, p.101-138, jan./dez. 2004 
uma longa memória" (ibid., p.84). A constituição do sujeito na experiência histórica narrada por Foucault é uma ação dirigida ao futuro, ao devir, destinada a se perpetuar na memória; uma ação de espera e esperança de acordo com as possibilidades e probabilidades de algo vir a ser real (realizado). Nos eixos da experiência considerados, a perspectiva é semelhante.

O regime dos prazeres na dietética tem por objeto o cuidado com o corpo, não para empurrá-lo para além de suas capacidades naturais, mas para segui-lo na completude de seus limites, sem antecipá-los por motivo de dispêndio de energia. O bom uso do corpo pelo indivíduo tem também como uma de suas funções o cuidado com a progenitura e com o futuro de sua família, bem como, em outra escala de valor, o futuro da espécie, esta ligada ao "princípio da reprodução, na medida em que coloca como finalidade da procriação paliar o desaparecimento dos seres vivos e dar à espécie, tomada no seu conjunto, a eternidade que não pode ser concedida a cada indivíduo" (ibid., p.121). Já a econômica, no movimento que segue da condição matrimonial doméstica chegando em uma idéia mais abrangente de vida civil, ou cidadania, é o caso de projeções relativas à boa gerência dos bens, conservando e ampliando estruturas materiais da família, mas também relativas ao destino do grupo social, ao bom governo das pessoas e à boa administração da cidade. A qualidade de chefe de família funciona como parâmetro para um bom governante e para um futuro desejado para a pólis. $\mathrm{Na}$ erótica, por sua vez, a escolha dos rapazes e a condição entre ativo e passivo na relação envolvem critérios e valores que concernem à manutenção da honra e do status do indivíduo. O perigo constante de se estabelecer um vínculo vergonhoso, marcado pelo excessivo poder exercido entre os parceiros, tornava-se, então, problemático. Afinal, era uma relação entre indivíduos do mesmo sexo, embora de idades diferentes, em que a atividade ou passividade do rapaz em relação ao homem dizia respeito à futura posição de tal jovem na cidade.

Enfim, nas palavras de Foucault, "a exigência de austeridade implicada pela constituição desse sujeito senhor de si mesmo não se apresenta sob a forma de uma lei universal, à qual cada um e todos

Anos 90, Porto Alegre, v. 11, n. 19/20, p.101-138, jan./dez. 2004 
deveriam se submeter; mas, antes de tudo, como um princípio de estilização da conduta para aqueles que querem dar à sua existência a forma mais bela e realizada possível" (ibid., p.218). A expectativa é projetada em direção a uma vida "bela", marcando, de certa maneira, a permanência do indivíduo para além dos limites físicos de sua existência, através de uma experiência memorável.

$\mathrm{Na}$ análise das duas obras que se utilizam do conceito de experiência, procurei o entendimento das funções desse conceito no interior do texto em que está inserido, articulando temporalidades variadas e organizando-as no tempo de uma narrativa específica. Tanto em $A$ formação da classe operária inglesa quanto em $O$ uso dos prazeres, o que se objetiva é uma ação particular, a constituição de sujeitos históricos, porém, no primeiro caso, a experiência é orientada do passado para um presente, enquanto que, no segundo caso, ela se orienta do presente para um futuro. Todavia, não é por si só suficiente essa simples constatação, a de que Thompson e Foucault utilizam o conceito de experiência de modo semelhante (enquanto campo de ação para determinado sujeito), embora com uma diferença fundamental de sentido (a experiência em relação ao passado, para um, e ao futuro, para outro). Certamente a tradição intelectual à qual ambos se filiam desempenha aí preponderante influência, com conseqüências capitais para o entendimento que fazem da história, as quais são esboçadas em artigo já mencionado (Albuquerque Jr., 2002). Entretanto, elas explicam pouco sobre o sentido temporal dado à experiência pelos autores, tema restrito do presente estudo.

Seria possível argumentar-se que o apego de Thompson ao romantismo desviaria seu olhar para o passado, enquanto que, para Foucault, pertinente mais à sua biografia, tratar-se-ia de uma constante recusa em permanecer imóvel, no anseio de sempre se deslocar e inventar novos "modos de vida". Não obstante, em decorrência mesmo da perspectiva aqui assumida, a pergunta que se

Anos 90, Porto Alegre, v. 11, n. 19/20, p.101-138, jan./dez. 2004 
coloca é menos sobre o porquê de uma tal escolha e mais sobre as implicações dela na feitura do texto historiográfico. Essa opção não desconsidera o âmbito contextual do texto, mas apenas restringe o olhar para a superfície do escrito, isto é, os elementos textuais da narrativa.

O fato de eles partirem de determinações teóricas diferentes acarreta, por conseguinte, concepções díspares de sujeito e de processo de subjetivação. Coerente em sua postura, Thompson enfatiza a lógica do processo ou o que define como "status ontológico do passado". Dessa maneira, uma história una constitui-se a partir de diversas outras histórias, "de modo que todas essas 'histórias' distintas devem ser reunidas no mesmo tempo histórico real, o tempo em que o processo se realizada" (Thompson, 1981, p.111). No anseio de explicitar o papel determinante da agência humana nesse processo constituído de inteligibilidade e intenções, segundo os pressupostos do materialismo histórico ao qual se filia, o historiador inglês acaba por desenvolver uma concepção teleológica da subjetividade, pois, seguindo seu raciocínio, se a classe estava presente em seu próprio fazer-se, as intenções de fazê-la também estavam presentes desde o início de sua formação. Nesse processo linear das últimas décadas do século XVIII até precisamente o ano de 1832, a classe aparece, então, como um sujeito unificado em um presente segundo condições estabelecidas pelo seu "espaço de experiência", isto é, pelo seu passado. Se a lógica da ação não implica uma lei, nela está inserida desde logo uma "teleologia do sujeito", de um sujeito como fundamento da história.

A expressão "teleologia do sujeito" é também utilizada por Foucault, embora com um sentido profundamente desigual. Neste caso, trata-se de colocar o sujeito em um tempo que não se realiza, jamais se tornando presente, ou seja, um futuro sempre empurrado para mais adiante. Foucault não assume uma identidade do processo histórico que possibilitaria uma concepção unificada de sujeito, mas atribui à história uma lógica dos acasos. A genealogia foucaultiana espreita os acontecimentos tidos como sem história no anseio de reencontrar o momento em que ainda não aconteceram. Isso não

Anos 90, Porto Alegre, v. 11, n. 19/20, p.101-138, jan./dez. 2004 
quer dizer, em absoluto, tratar-se de uma pesquisa de origem, este "desdobramento meta-histórico das significações ideais e das indefinidas teleologias" (Foucault, 1998, p.16). A genealogia é a paciente procura dos começos históricos, lá onde não há uma identidade originária, apenas o disparate dos acasos, daquilo que é já começado; o genealogista, por sua vez, faz descobrir "que na raiz daquilo que nós conhecemos e daquilo que nós somos - não existem a verdade e o ser, mas a exterioridade do acidente" (ibid., p.21). Nessa linha de raciocínio, não há uma origem fundadora para a subjetividade, e o sujeito plenamente constituído apenas aparece como disperso em um futuro inatingível, estando sempre por se realizar na e pela história.

Thompson consegue vislumbrar, em um momento específico, uma classe plenamente formada através de um processo de luta, consciente de seus interesses antagônicos em relação a outra classe. Se a experiência narrada era a da formação dessa classe, a narrativa pode ser interrompida nesse momento oportuno, o ano de 1832. Já há, configurada no texto, uma ação una e completa: o sujeito histórico aparece inteiramente constituído, o que não implica o encerramento de uma história, mas o fechamento de uma narrativa - "mas os trabalhadores não devem ser vistos apenas com as miríades de eternidades perdidas. Também nutriam, por cinqüenta anos e com incomparável energia, a Árvore da Liberdade. Podemos agradecer-lhes por esses anos de cultura heróica" (Thompson, 1987a, v.III, p.440). Em Foucault, a ação não atinge seu termo, não emerge em determinado momento do texto um sujeito plenamente constituído; a narrativa não se conclui em um ponto derradeiro, ela apenas indica a direção ao futuro, ao próximo volume da longa história da experiência ampla da sexualidade. O texto é encerrado, e a intriga fecha-se no limite do livro, com um espaço configurado de uma ação possível, mas a experiência da subjetividade permanece e desloca-se: a ética cristã será diferente, e, depois dela, nos próximos volumes, outros deslocamentos. Não interessa a ele a duração da ação, mas seu campo de possibilidade; a ação narrada é sempre uma ação possível, uma ação a ser realizada.

Anos 90, Porto Alegre, v. 11, n. 19/20, p.101-138, jan./dez. 2004 
Na base de tais concepções, esboça-se um lugar particular, com suas determinações específicas na construção de cada texto. Para Thompson, seu escopo é bastante claro: se a experiência é um processo com uma lógica própria e una, "em última análise, a lógica do processo só pode ser descrita em termos de análise histórica; nenhuma analogia derivada de qualquer outra área pode ter mais que um valor limitado, ilustrativo e metafórico" (Thompson, 1981, p.97). Em decorrência, a conseqüência óbvia para ele é que "o materialismo histórico deve, neste sentido, ser a disciplina na qual todas as outras disciplinas humanas se encontram [...] a História deve ser reconduzida a seu trono como rainha das humanidades..." (ibid., p.83). É bem verdade que, para evitar o imperialismo epistemológico, Thompson adverte que a disciplina história é também a mais imprecisa, devendo sempre estar atenta a seus pressupostos teórico-metodológicos. O que se salienta é que a lógica histórica é o próprio discurso de comprovação da história, aquilo que a legitima como conhecimento. Foucault é enfático de outra maneira, e seu escopo é justamente o contrário da defesa de um território. No seu entendimento, trata-se de realizar a crítica da perspectiva metafísica da história que, segundo o modelo antropológico de um sujeito fundador e unificado, busca inserir, na continuidade de uma origem, um lugar para a identidade. Para ele, "saber, mesmo na ordem histórica, não significa 'reencontrar' e sobretudo não significa 'reencontrar-nos'. A história será 'efetiva' na medida em que ela reintroduzir o descontínuo em nosso próprio ser" (Foucault, 1998, p.27).

Em suma, da parte de um, a história é construção de uma identidade histórica para determinado sujeito, mostrando de onde ele se originou e o que ele é ou está para ser; da parte do outro, ela é a prática de rarefação da identidade, do desvanecer do sujeito, mostrando o que ele deixou de ser e o que não é mais nem é ainda. $\mathrm{O}$ conceito de experiência, da maneira como aparece nos textos de cada um desses autores, é devedor de suas respectivas posturas teóricas e de suas diferentes concepções de história, mas, no interior da intriga armada, tanto para um quanto para outro, tal conceito organiza o

Anos 90, Porto Alegre, v. 11, n. 19/20, p.101-138, jan./dez. 2004 


\section{A narrativa da experiência em Foucault e Thompson}

sentido da história e confere significado para a ação realizada e, vale dizer, narrada.

\section{The narrative of experience in Foucault and Thompson}

Abstract. The text analyzes the concept of experience in Michel Foucault's and Edward Thompson's works, specifically the way both organize, in the historical narrative, a particular action, characterized by the temporality of the construction of a historical subject.

Keywords: Michel Foucault. Edward Thompson. Experience.

\section{Notas}

${ }^{1}$ Aviso desde já que não me deterei aqui nos escritos de Ricoeur e Koselleck, o que demandaria outro artigo específico. Quando necessário, indicarei as obras nas quais baseei minhas considerações.

${ }^{2}$ Para o prefácio à primeira edição de História da loucura, ver Foucault (1999, p.140-148); para seu último texto, ver Foucault (2000, p.352-366).

${ }^{3}$ Este texto é uma versão modificada do prefácio à tradução americana do livro do epistemólogo francês, O normal e o patológico, publicado em 1985 no número da Revue de Métaphysique et de Morale que tematizava a obra de Canguilhem.

${ }^{4} \mathrm{Em}$ seu primeiro escrito publicado, uma introdução de 1954 a $O$ sonho e a existência, do psicanalista suíço Ludwig Binswanger, já aparece a utilização do termo, embora trate-se de um texto "rejeitado" por Foucault. Quanto aos comentários, é possível citar alguns mais explícitos: Godinho (1993, p.27-34); Marcos (1993, p.131-136); Souza (2000).

${ }^{5}$ De acordo com essa noção, Foucault considera que há semelhanças entre os conhecimentos de cada experiência em particular, os quais são profundamente diferentes dos conhecimentos das experiências anterior ou posterior. Desse modo, segundo o autor, a biologia é muito mais parecida com a economia política, ambas pertencentes à experiência epistemológica moderna, do que com a história natural da episteme clássica.

${ }^{6}$ Para um ensaio fundamental que define a genealogia foucaultiana, ver o capítulo Nietssche, a genealogia e a história, em Foucault (1998, p. 15-38). Ali se encontra um dos pressupostos fundamentais desta prática: "nada no homem - nem mesmo seu corpo - é bastante fixo para compreender outros homens e se reconhecer neles" (p. 27).

${ }^{7}$ Quanto à questão da configuração da ação, apenas remeto para os estudos sobre a tríplice mímese realizados por Ricoeur (1994).

${ }^{8}$ Em Discourse and truth: the problematization of parrhesia, Foucault (1983) define esse procedimento como o estudo sobre "o modo como instituições, práticas,

Anos 90, Porto Alegre, v. 11, n. 19/20, p.101-138, jan./dez. 2004 


\section{Fernando Nicolazzi}

hábitos e comportamentos se tornam um problema para as pessoas que se comportam de maneira específica, que têm certos hábitos, que se engajam em certos tipos de práticas e que constroem tipos singulares de instituições”. Um ano mais tarde, em entrevista, complementa tal definição: "problematização não quer dizer representação de um objeto preexistente, nem criação pelo discurso de um objeto que não existe. É o conjunto das práticas discursivas ou não discursivas que faz alguma coisa entrar no jogo do verdadeiro e do falso e a constitui como objeto para o pensamento (seja sob a forma de reflexão moral, do conhecimento científico, da análise política etc.)" (Foucault, 1984b, p. 76).

${ }^{9}$ Para a questão específica do sujeito nos escritos de Foucault a partir de 1976, segundo o recorte do tema da amizade e subjetividade, ver Ortega (1999). Para uma síntese mais generalizante e por vezes pouco convincente, ver Araújo (2000). ${ }^{10}$ Postura semelhante à de Foucault genealogista, que criticava o fato de que "os historiadores procuram, na medida do possível, apagar o que pode revelar, em seu saber, o lugar de onde eles olham, o momento em que eles estão, o partido que eles tomam - o incontrolável de sua paixão" (Foucault, 1998, p. 30).

${ }^{11}$ Para tais questões, limito-me apenas a algumas referências bibliográficas: Johnson (1983); Samuel (1984); Anderson (1985); Kaye (1990); o número especial Diálogos com E. P. Thompson, da revista Projeto História. Revista do Programa de Estudos Pós-Graduados em História e do Departamento de história da PUC/SP, n. 12, out. 1995; e Palmer (1996).

${ }^{12}$ Para a noção de texto como paradigma de análise de uma reflexão teórica sobre a prática dos historiadores, remeto a outro artigo no qual a desenvolvo com mais precisão (Nicolazzi, 2003, p. 45-76).

${ }^{13}$ Sobre esse ponto, ver o capítulo Classe como processo e como relação, de Wood (2003, p. 73-98).

${ }^{14}$ No livro em questão, o autor não se detém sobre a classe contra a qual a consciência operária construiu-se a si mesma, tomada desde o início como dado objetivo pronto. Nesse sentido, ele desconsidera, em sua análise, as possíveis e recíprocas influências que a instituição de interesses e valores por ambas as classes, em seus processos de formação diferentes mas profundamente imbricados um no outro, tiveram em suas experiências.

${ }^{15}$ Em outra ocasião, no texto As peculiaridades dos ingleses, o autor sustenta que a definição de classe "só pode ser feita através do tempo, isto é, ação e reação, mudança e conflito [...] classe, mesmo, não é uma coisa, é um acontecimento" (Thompson, 2001, p. 169).

${ }^{16}$ William H. Sewell (1990, p.58-59) contrapõe a essa idéia o argumento de que a própria noção de relação (a classe como relação) é profundamente sincrônica, pois a ela convergem fatores díspares em um determinado recorte de tempo e aponta para o fato de que o próprio texto de Thompson, ao tratar diacronicamente do surgimento da classe, é repleto de análises pontuais e sincrônicas.

Anos 90, Porto Alegre, v. 11, n. 19/20, p.101-138, jan./dez. 2004 


\section{A narrativa da experiência em Foucault e Thompson}

${ }^{17}$ Segundo Keith McClelland (1990, p.3), tal é o mérito da obra de Thompson, a saber, de que "é possível para as pessoas fazer de si mesmas algo diferente do que aquilo que a história fez delas". Sewell Jr. (1990, p.65) compartilha tal visão e aponta para a relação desse processo concreto com sua narrativa, sugerindo que "Thompson não desenvolve uma elaborada teoria do sujeito, mas passa boa parte do tempo construindo sujeitos em sua narrativa".

${ }^{18}$ Ver o capítulo A economia moral da multidão inglesa no século XVIII (Thompson, 1998, p. 150-202). O original desse texto data de 1971, embora a expressão “economia moral” apareça já em A formação da classe operária inglesa, de 1963.

${ }^{19} \mathrm{O}$ autor aponta ainda o fato de que, apesar da influência "regressiva e estabilizadora”, o metodismo foi responsável, embora indiretamente, por uma melhora na auto-estima e na capacidade de organização do operariado (Thompson, 1987a, p. 42 e ss).

${ }^{20}$ Esse conflito é analisado pelo autor também em outro trabalho historiográfico (Thompson, 1987b).

${ }^{21}$ Ao invés do disparate comum atribuído pelos estudiosos das massas do século XIX, Thompson aparece como expoente dos estudos que "devolveram" racionalidade política à ação social das multidões. Ver, a esse respeito: Julia (1998, p. 217-232); Desan (1995, p. 63-96); e Davis (1990), especialmente o capítulo Razões do desgoverno (p. 87-106).

${ }^{22}$ O próprio autor, em entrevista de 1976, vale-se do termo "versão estruturalista", para se referir ao capítulo intitulado Exploração, da segunda parte do livro. Salienta ainda de modo enfático que "nenhum marxista pode não ser estruturalista, em certo sentido" (Thompson, 1984, p. 310). Apesar disso, no texto Folclore, antropologia e história social, não deixa de traçar críticas à transposição de modelos estruturalistas da antropologia, isto é, de Levi-Strauss, para a análise historiográfica, além da famosa querela contra o estruturalismo althusseriano (Thompson, 2001, p. 248-249).

${ }^{23}$ A perspectiva cultural do autor ultrapassa a simples formulação teórica e incide decisivamente na prática, isto é, no acesso empírico pelo documento. Thompson vale-se sobremaneira de fontes tais como relatos, diários, cartas etc; todo um aparato que lhe permitisse recuperar as "minorias com linguagem articulada".

${ }^{24}$ Em passagem famosa do livro A formação da classe operária inglesa, Thompson (1987a, v.II, p.18) afirma que "a classe operária formou a si própria tanto quanto foi formada".

${ }^{25}$ Esse posicionamento é motivo de uma das críticas ao livro feitas por Perry Anderson em seu debate no interior do marxismo inglês, na obra Teoría, politica e historia. Un debate con E. P. Thompson (1985), cujo título original é Arguments within English marxism.

${ }^{26}$ Norberto Ferrera (1999, p.360-375), talvez de maneira apressada, percebe, além das controvérsias, uma aproximação de Thompson com a chamada "virada lingüística", a partir das relações entre a experiência de classe e seu próprio discurso.

Anos 90, Porto Alegre, v. 11, n. 19/20, p.101-138, jan./dez. 2004 


\section{Fernando Nicolazzi}

${ }^{27}$ Conforme o texto As peculiaridades dos ingleses (Thompson, 2001, p. 75-180). Uma década após, em Modos de dominação e revoluções na Inglaterra, Thompson afirma ainda essa idéia, deixando, contudo, uma certa incoerência de pressuposto: "é preciso levar a sério a autonomia dos acontecimentos políticos e culturais que são, todavia, em última análise, condicionados pelos acontecimentos 'econômicos" (Thompson, 2001, p. 207).

${ }^{28}$ Nesse sentido, talvez, não seja demais argumentar que a influência weberiana em sua obra transcende alguns comentários feitos a respeito dos estudos sobre ética protestante e espírito capitalista, no capítulo dedicado ao metodismo de $A$ formação..., influência essa aparente no papel preponderante da cultura na formulação teórica e no olhar prático de Thompson. Vale citar, por exemplo, uma passagem de um dos mais conhecidos ensaios teóricos de Max Weber, segundo quem o conceito de cultura é ele mesmo um julgamento de valor e para quem a ciência tem por mérito fazer notar que "toda atividade e, bem entendido também, segundo as circunstâncias, a inação, significam por suas conseqüências uma tomada de posição em favor de certos valores e do mesmo modo, em regra geral - se bem que hoje em dia se esquece disso voluntariamente - contra outros valores" (Weber, 1965, p. 124).

${ }^{29}$ São vários os comentadores que discutem de maneiras diferentes tal conceito em Thompson. Como exemplos, ver: Anderson (1985); Sewell Jr. (1990); e Renk (1996, p. 78-104).

${ }^{30}$ Trata-se de um junction concept, cuja junção se desdobra em experiência I, vivida no social, e experiência II, percebida e elabora pela consciência (Thompson, 1984, p.314).

${ }^{31} \mathrm{O}$ "espaço de experiência" diz respeito a um passado tornado presente, marcado pela recordação elaborada racionalmente e também pela lembrança gravada inconscientemente. O "horizonte de expectativa" remete a um futuro feito presente, segundo a perspectiva aberta pela projeção e pela espera. Assim, passado e futuro assentam suas presenças de maneiras distintas, assim como o presente é situado na coordenação assimétrica entre o passado e o futuro. Para tais conceitos, remeto a Koselleck (1993, p. 333-357), onde consta a seguinte formulação: “'experiência' e 'expectativa' são apenas categorias formais [...] A antecipação formal de explicar a história com estas expressões polarmente tensas, unicamente pode ter a intenção de perfilar e estabelecer as condições das histórias possíveis, mas não as histórias mesmas. Trata-se de categorias do conhecimento que ajudam a fundamentar a possibilidade de uma história”.

\section{Referências}

ALBUQUERQUE Jr., Durval Muniz. Experiência: uma fissura no silêncio. Territórios e fronteiras, v.3, n. 1, p.61-75, 2002.

Anos 90, Porto Alegre, v. 11, n. 19/20, p.101-138, jan./dez. 2004 


\section{A narrativa da experiência em Foucault e Thompson}

ANDERSON, Perry. Teoría, politica e historia: un debate con E. P. Thompson. Madrid: Siglo Veintiuno de España Ed., 1985. Original: Arguments within English marxism.

ARAÚJO, Inês Lacerda. Foucault e a crítica do sujeito. Curitiba: Editora da UFPR, 2000.

DAVIS, Natalie Zemon. Culturas do povo: sociedade e cultura no início da França moderna. Trad. Mariza Corrêa. Rio de Janeiro: Paz e Terra, 1990.

DE DECCA, Edgar Salvadori. E. P. Thompson: um personagem dissidente e libertário. Projeto História. Revista do Programa de Estudos Pós-Graduados em História e do Departamento de história da PUC/SP, n. 12, out. 1995.

DESAN Suzanne. Massas, comunidade e ritual na obra de E. P. Thompson e Natalie Davis. Trad. Jefferson Luís Camargo. In: HUNT, Lynn. A nova história cultural. São Paulo: Martins Fontes, 1995.

ESCOBAR, Carlos Henrique de (Org.). Dossier Michel Foucault: últimas entrevistas. Rio de Janeiro: Taurus, 1984.

FERRERA, Norberto O. Culturalismo e experiência: leitura dos debates em torno da obra de E. P. Thompson. Diálogos, v. 3, n. 3, 1999.

FOUCAULT, Michel. Discourse and truth: the problematization of parrhesia (1983). Disponível em: < http:/ /www.nakayama.org/polylogos/philosophers/ foucault/index-e.html $>$.

História da sexualidade II: o uso dos prazeres. Trad. Maria Thereza da Costa Albuquerque. Rio de Janeiro: Graal, 1984a.

FOUCALT, Michel. O cuidado com a verdade. In: ESCOBAR, Carlos Henrique de (Org.). Dossier Michel Foucault. últimas entrevistas. Rio de Janeiro: Taurus, 1984b.

O retorno da moral. In: ESCOBAR, Carlos Henrique de (Org.). Dossier Michel Foucault: últimas entrevistas. Rio de Janeiro: Taurus, 1984c.

As palavras e as coisas: uma arqueologia das ciências humanas. Trad. Salma Tannus Muchail. São Paulo: Martins Fontes, 1995.

A arqueologia do saber. Trad. Luiz Felipe Baeta Neves. Rio de Janeiro: Forense Universitária, 1997. 1998. Microfísica do poder. Trad. Roberto Machado. Rio de Janeiro: Graal,

A verdade e as formas jurídicas. Rio de Janeiro: Graal, 1999a.

Anos 90, Porto Alegre, v. 11, n. 19/20, p.101-138, jan./dez. 2004 


\section{Fernando Nicolazzi}

FOUCALT, Michel. Ditos e escritos I. Problematização do sujeito: psicologia, psiquiatria e psicanálise. Rio de Janeiro: Forense Universitária, 1999b.

Ditos e escritos II. Arqueologia das ciências e história dos sistemas de pensamento. Rio de Janeiro: Forense Universitária, 2000.

GODINHO, Jacinto. Foucault e a experiência: a fenomenologia do impensado. Revista de Comunicação e Linguagens, Lisboa, dez. 1993.

HOBSBAWM, Eric. E. P. Thompson. Trad. Antonio Luigi Nero. In: THOMPSON, Edward Palmer. As peculiaridades dos ingleses e outros artigos. Org. e trad. Antonio Luigi Nero e Sergio Silva. Campinas: Editora da Unicamp, 2001.

JOHNSON, Richard et. al. Hacia una historia socialista. Barcelona: Ediciones del Serbal, 1983.

JULIA, Dominique. A violência das multidões: é possível elucidar o desumano. Trad. Marcella Mortara e Anamaria Skinner. BOUTIER, Jean; JULIA, Dominique (Org.). Passados recompostos: campos e canteiros da história. Rio de Janeiro: Editora da UFRJ; Editora FGV, 1998.

KAYE, Harvey; McCLELLAND, Keith (Ed.). E. P. Thompson: critical perspectives. Philadelphia: Temple University Press, 1990.

KOSELLECK, Reinhardt. "Espacio de experiencia" y "horizonte de expectativa". Dos categorías históricas. In: _. Futuro pasado. Para una semántica de los tiempos históricos. Barcelona: Ediciones Paidos, 1993.

MARCOS, Maria Lucília. Experiência e problematização(ões). Revista de Comunicação e Linguagens, Lisboa, dez. 1993.

NICOLAZZI, Fernando. Uma teoria da história: Paul Ricoeur e a hermenêutica do discurso historiográfico. História em Revista, v. 9, dez. 2003.

ORTEGA, Francisco. Amizade e estética da existência em Foucault. Rio de Janeiro: Graal, 1999.

PALMER, Bryan. Edward Palmer Thompson: objeções e oposições. Trad. Klauss Brandini Gerhardt. Rio de Janeiro: Paz e Terra, 1996.

RENK, Arlene. A experiência em Thompson. História: questões e debates, Curitiba, jul./dez., p. 78-104, 1996.

RICOEUR, Paul. Tempo e narrativa. Trad. Constança Marcondes Cesar. Campinas: Papirus, 1994. Tomo I.

SAMUEL, Raphael (Ed.). Historia popular y teoría socialista. Barcelona: Crítica; Grijalho, 1984.

Anos 90, Porto Alegre, v. 11, n. 19/20, p.101-138, jan./dez. 2004 


\section{A narrativa da experiência em Foucault e Thompson}

SEWELL Jr, William H. How classes are made: critical reflections on E. P. Thompson's theory of working-class formation. In: KAYE, Harvey; McCLELLAND, Keith (Ed.). E. P. Thompson: critical perspectives. Philadelphia: Temple University Press, 1990.

SOUZA, Sandra Coelho de. A ética de Michel Foucault. a verdade, o sujeito, a experiência. Belém: Cejup, 2000.

TERNES, José. A morte do sujeito. In: BRANCO, Guilherme Castelo; PORTOCARRERO, Vera. Retratos de Foucault. Rio de Janeiro: Nau, 2000.

THOMPSON, Edward Palmer. A miséria da teoria ou um planetário de erros. Trad. Waltensir Dutra. Rio de Janeiro: Zahar, 1981.

Una entrevista con E. P. Thompson. In: Tradición, revuelta y consciencia de classe: estudios sobre la crisis de la sociedad preindustrial. Barcelona: Crítica, 1984.

A formação da classe operária inglesa. Trad. Denise Bottmann, Renato Busatto Neto e Cláudia Rocha de Almeida. Rio de Janeiro: Paz e Terra, 1987a. $3 \mathrm{v}$. Terra, 1987.

Senhores e caçadores. Trad. Denise Bottman. Rio de Janeiro: Paz e

Costumes em comum. Trad. Rosaura Eichemberg. São Paulo: Companhia das Letras, 1998.

As peculiaridades dos ingleses e outros artigos. Org. e trad. Antonio Luigi Nero e Sergio Silva. Campinas: Editora da Unicamp, 2001.

WEBER, Max. L'objectivité de la connaissance dans les sciences et la politique sociales. In: Essais sur la théorie de la science. Paris: Plon, 1965.

WOOD, Ellen Meiksins. Democracia contra capitalismo: a renovação do materialismo histórico. Trad. Paulo Cezar Castanheira. São Paulo: Boitempo, 2003.

Anos 90, Porto Alegre, v. 11, n. 19/20, p.101-138, jan./dez. 2004 